Vol. 2, No. 06; 2019

ISSN: 2581-4664

\title{
DETERMINANT OF E-GOVERNMENT AND GOOD GOVERNANCE :CASE IN THE ACEH PERSONNEL DEPARTMENT
}

\author{
Ibnu Khaldun, Rahman Lubis, Sofyan Idris \\ Department of Management, UniversitasSyiah Kuala, Indonesia \\ http://doi.org/10.35409/IJBMER.2019.2430
}

\begin{abstract}
This research is conducted to test the effect among information technology, human resource (HR), organizational culture, e-government and good governance. The object is the Aceh Personnel Department (BKA), and the respondents are the employees of it as much as 127 people that taken by a cencus method.

The data is processed by Structural Equation Model (SEM) with AMOS software. The result proves that information technology has a significant effect on e-government; human resources has a significant effect on e-government; organizational culture has a significant effect on egovernment; information technology has a significant effect on good governance; human resources has a significant effect on good governance; organizational culture has a significant effect on good governance, and; e-government has a significant effect on good governance. These research findings have implications that efforts to implement good governance in these institutions can be done through policy interventions related to improving information technology, increasing the quality of employee HR and the implementation of organizational values and culture. These also contribute to the science area that can be an update causality theories related to the variables. This model is able to be a reference for the further research especially in the field of management and organization. The originality lies in the combination of the models fro the previous causality theories, and the test method using SEM. The limitation is in the number of variables and object.
\end{abstract}

Keyword: Information technology, human resource, organizational culture, e-government and good governance.

\section{INTRODUCTION}

In the framework of implementing good and right government (good governance) it becomes one of the important issues especially for the management of public administration. In order to improve good governance, the government seeks to implement electronic government.

The implementation of e-government by regional governments is certainly related to various factors such as information technologyinfrastructure, readiness of human resources (HR) and organizational culture of government agencies. This is due to the success of the implementation of e-government is largely determined by the support of all government officials 


\section{International Journal of Business Management and Economic Review}

Vol. 2, No. 06; 2019

ISSN: 2581-4664

and their level of readiness in implementing the program. In addition, the work culture of public organizations such as government agencies can also be a driving factor or an obstacle to the implementation of e-government. Moreover, organizational culture is related to the values and norms that are respected by all members of the organization. So that the seriousness of the government apparatus in supporting the success of e-government will be related to the organizational culture that applies to the Department where they work.

Information technology infrastructure is related to the joint use of information technology resources consisting of hardware such as technological devices and software such as the ability of humans to develop programs for technology development for improving organizational progress (Byrd and Turner, 2000). The implementation of e-government in government agencies such as the Aceh Personnel Department (BKA) certainly requires the support of information technology infrastructure. BKA is one of Aceh government department that manage the personnel of civil servants of Aceh Province. The importance of information technology infrastructure in supporting the implementation of e-government is caused by the application of e-government requires the availability of information technology as an important determinant in supporting the program. Without good information technology, the implementation of egovernment in government agencies cannot be implemented as expected.

Furthermore, HR or employee quality can also influence the implementation of egovernment. The application of e-government requires employees who have good capacities and abilities, especially capabilities related to the use of information technology. The success of implementing e-government is largely determined by the ability of government officials to support the program. This means that the quality ofHR at the BKA can influence the success of the implementation of e-government to support the implementation of good governance in the Department.

In accordance with the differences in work placement / field of work and class, the work ability of each employee of the Department is certainly also different. And the difference in work ability is actually an important consideration for the personnel Department in determining the employment placement of an employee. This indicates that in terms of certain occupations, the quality of the BKA HR is also different. An employee who works in a particular field of work such as the field of program and reporting, for example, does not necessarily have sufficient knowledge when he must be placed in the field of information systems and telematics technology. Vice versa. However, each employee is at least required to be able to support the implementation of e-government in the Department. Proficiency in using technological infrastructure becomes a necessity by every employee, so that the implementation of egovernment can be supported by qualityHR, at least in the mastery of information technology.

This phenomenon is related to the results of research conducted by (Ruslan, Mukhlis and Mahdani, 2015), which stated that the quality of human resources or knowledge possessed by some employees has an influence on improving employee performance.

The observations of the researchers indicate that the quality ofHR at the BKA is different from other agencies. Differences in the quality ofHR can be seen from their educational background, training followed and compliance with laws and regulations related to employment. The existence of some employees with relatively low levels of education such as class I and II employees, for example, is an important indication of the problem of the quality ofHR in the Department. In addition, the existence of some employees with a low level of mastery of 


\section{International Journal of Business Management and Economic Review}

Vol. 2, No. 06; 2019

ISSN: 2581-4664

information technology to support the implementation of e-government is also a clear evidence of HR issues at the BKA.

This phenomenon is consistent with research conducted by (Sagita, Musnadi and Shabri, 2017) where the application of good governance affects the performance of regional governments.

Regarding the availability of information technology infrastructure in supporting its operations, BKA has a relatively good information technology infrastructure. Even though in certain fields of work, the availability of infrastructure is still considered inadequate, but has not negatively impacted the smooth implementation of duties by employees. information technology infrastructure that is intended as hardware and computer software, Department software, which can facilitate employees in carrying out tasks assigned.

The phenomenon related to technology is consistent with the research of (Mahdani, 2009) where the technological environment has a role in improving employee performance.

In terms of the implementation of good governance it is known that BKA is an important part in supporting the implementation of the good governance. The implementation of good governance at the BKA can be seen, among others, from the support of these agencies to increase transparency and accountability. Until now, the public can access information directly related to the performance of the Department through the website provided. So that the community and all relevant stakeholders can provide an assessment of the performance and capabilities of agencies in providing public services.

Phenomena related to the application of the principles of good governance in these institutions are perceived differently by employees. The results of the initial survey using interviews with a number indicate that not all employees have a good assessment of the principle of transparency in the Department. In addition, the effectiveness and efficiency of activities that should be one of the important indicators for the application of the principles of good governance are also considered not fully manifested in the operational activities of the Department. Furthermore, relating to accountability as one of the important indicators of the implementation of good governance, it is also perceived to be relatively different by employees. There are still among employees who state the lack of accountability of activities in the Department. Even though most employees already have relatively good perceptions of accountability and transparency at the BKA, there are still employees who have poor perceptions of this indicating the existence of problems with respect to implementing good governance principles.

\section{LITERATURE REVIEW}

\section{Good Governance}

The implementation of governance principles in the governance system should be focused on developing human resources first, so that the readiness of these human resources to implement government management is better and runs in accordance with the prevailing legal corridors (Pratikno, 2005).

Other institutions, such as the Commission on Global Governance, also describe the notion of governance as being equivalent to the definition above. Governance is defined as the capacity of individuals and institutions, public and private to manage common affairs (Pratikno, 2005). In this process the application of e-governance should be able to accommodate all the various interests and sometimes collide with each other that will be accommodated, collaborated 


\section{International Journal of Business Management and Economic Review}

Vol. 2, No. 06; 2019

ISSN: 2581-4664

or synergized, so as to reach agreement with formal institutions that can guarantee all compliance of all parties.

\section{E-Government}

E-government has not been a key factor in increasing political freedom and democratic institutions, although it gives citizens new opportunities to express their views. e-government is used to improve the efficiency and effectiveness of the government, and to provide better information and seek feedback from every member of the organization (Kumar and Best, 2006).

E-Government describes the use of information and communication technology (ICT) to support government operations in carrying out their functions to be even better. This technology can serve citizens in different ways, namely better service for citizens, good interaction with business and industry, more efficient government management, and others (Khanh, 2014). But with the help of sophisticated computer technology, it is possible to find service centers that are closer to people. Examples of such centers include e-seva which provides various services such as aadhar, ration cards, income services, etc., for the general public. The benefits of implementing eGovernment are reducing corruption in government offices, transparency, comfort, revenue growth, and others

Furthermore e-government aims to make interactions between government and citizens, government to business, government to government and government to employees. Interaction between the Government and other Agencies. e-government is mostly related to computer and internet connections and also includes other ICT applications such as cellular telephones, satellite communications and geographic information systems. The next section deals with some basic applications of e-government with brief information (Mohamed, Haderi and Ahmed, 2015).

\section{Information Technology (IT)}

Governance can be seen broadly as a system for directing and coordinating collective action. However, the realm of public action goes beyond the concept of public delivery and stateled change. The role of the state is transformed from a sovereign to a ruler based on the coordination and fusion of public and private resources. New modes of policy consultation are being tried to increase citizen involvement in the policy deliberation process. Information tools such as electronic websites are used to enable various stakeholders to convey their perceptions aboutpublic problems(Indrajit, 2002). Given the insistence on political innovation in the community, it is important to gain a solid understanding of how new information systems can improve the quality of governance in ways that will meet the demands of citizens. This study, therefore, seeks to assess the role of IT in promoting good governance.

\section{Human Resources (HR)}

It needs to be realized that to compensate for changes and progress in various aspects that affect an organization is demanded for the availability of workers who can fulfill their needs at any time. For that, there is a need for leaders who can manage resources effectively and efficiently. In conditions like this, the staffing Department is also required to always have a new strategy to be able to develop and maintain capable employees needed by an Department(Tunggal, 1995).

The role of human resource management in organizations is not just administration but 


\section{International Journal of Business Management and Economic Review}

Vol. 2, No. 06; 2019

ISSN: 2581-4664

rather leads to the ability to develop the potential of human resources to be creative and innovative. In public organizations such as government agencies, Civil Servants (PNS) are the main elements of human resources / state apparatuses that have a role in determining the success of governance and development (Suharto, 2012).

Based on the description above it can be concluded that human resources (HR) is an employee who manages or is related to the activities of operating and maintaining the system so that it can function optimally and sustainably in an employee management information system in an organizational unit. TheHR intended in this study are employees of the Aceh Personnel Department which if associated with the implementation of e-government can be seen as one of the important requirements for the implementation of e-government programs to create good governance in the Department.

\section{Organizational Culture}

The condition of the organization is strongly influenced by the work culture of the organization. Culture has full strength, affects individuals and their performance even on the work environment. (Harris and Mossholder, 1996) state that organizational culture stands as the center of all factors derived fromHR management. organizational culture is believed to influence individual attitudes regarding results, such as commitment, morale, satisfaction and work motivation.

Whereas(Robbins and Judge, 2012) views culture as a general perception held by members of an organization that is characteristic of how workers feel something in the organization.

Based on some of the opinions above, it can be concluded that organizational culture are assumptions and patterns of fundamental meanings and adhered to and manifested by all parties participating in an organization which is influenced by the work culture of the organization and influences individuals and their performance even on the work environment.

\section{Research Paradigm}

From the discussion above, the authors fomulate the research model and hypothesis as follow.

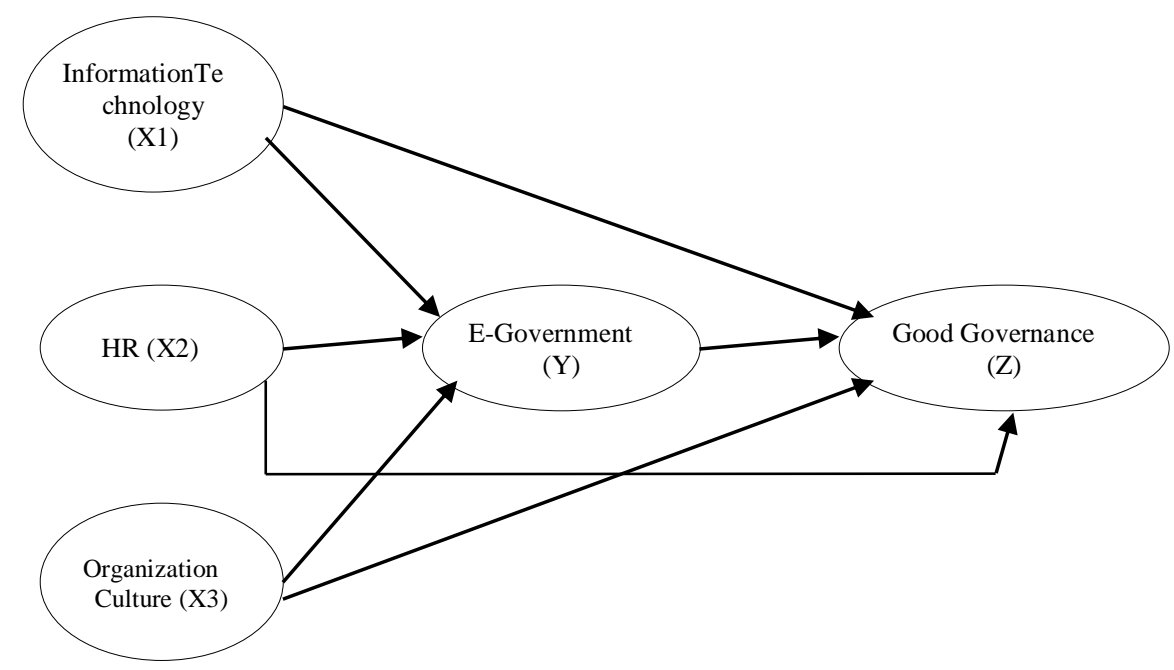




\section{International Journal of Business Management and Economic Review}

Vol. 2, No. 06; 2019

ISSN: 2581-4664

Figure 1. Conceptual Framework

H1 : information technology has a significant effect on e-government

$\mathrm{H} 2$ :HR has a significant effect on the implementation of e-government

$\mathrm{H} 3$ : organizational culture has a significant effect on the implementation of e-government.

$\mathrm{H} 4$ :. information technology has a significant effect on good governance

H5 :HR has a significant effect on good governance.

H6 : organizational culture has a significant effect on good governance.

$\mathrm{H} 7$ : e-government has a significant effect on good governance.

\section{RESEARCH METHOD}

Research is conducted at the Aceh Personnel Department. The variablesare the application of e-government and good governance that are associated with information technology, HR and organizational culture. The application of e-government does not only act as a predictor of variables for good governance, but also as a mediating variable between information technology, HR and organizational culture and good governance.

The HR intended in this study are the quality ofHR, namely the ability of employees to carry out the tasks assigned that are seen from the skills of a person, educational background, requirements that must be followed to be able to occupy work positions, trainings, professional problems and socialization of regulations that changes. The assessment of good governance is only based on the assessment of employees of the Aceh Personnel Department. This is based on the reason that Department employees are seen as the main supporting factors in the Department's operational activities in implementing the principles of good governance, especially if it is associated with the implementation of e-government.

The object is the Aceh Personnel Department, and the respondents are the employees of it as much as 127 people that taken by a cencus method.The data is processed by Structural Equation Model (SEM) with AMOS software. SEM is a multivariate statistic technique in order to analyze the influence not only between variables, but also the relationship with the indicator variables respectively. Ha acceptance criteria is Critical Ratio (CR)> 1.96 and the Probability (P) $<0.05$.

\section{RESULT}

\section{H1 is accepted : The Effect of information technology on e-government}

The effect of information technology on e-government shows a CR value of 4.396 and a probability of 0.000 . Thus it can be concluded that the use of information technology will influence the increase of e-government in the Aceh Personnel Department. The information technology applied will also have a positive and tangible influence in order to improve egovernment.This figures that the better the information technology infrastructure, the better the application of e-government to the Department. Conversely, when the quality of information infrastructure decreases, these conditions can have a negative impact on the implementation of egovernment. 


\section{International Journal of Business Management and Economic Review}

Vol. 2, No. 06; 2019

ISSN: 2581-4664

\section{H2 is accepted : The Effect of HR on e-government}

The effect of HR quality on e-government shows a CR value of 3.321 and a probability of 0.000 . Where the value is the condition for acceptance of $\mathrm{H} 3$, that is the $\mathrm{CR}$ value of 3.321 which is greater than the table value of 1.97. This indicates that improving the quality ofHR can also significantly affect the implementation of e-government. The more qualityHR the better the implementation of e-government in the Aceh Personnel Department.

\section{H3 is accepted : The Effect of organizational culture on e-government}

The influence of organizational culture on e-government shows a CR value of 3.095 and a probability of 0.000 . Where the value is fulfilled the conditions for acceptance $\mathrm{H} 2$, namely CR value of 3.095 which is greater than the table value of 1.97 . This indicates that the better the organizational culture manifested in the form of values and norms that applies in the Aceh Personnel Department, the better the implementation of e-government in the Department.

\section{H4 is accepted : The Effect of information technology on good governance}

The effect of information technology on good governance shows a CR value of 4.196 and a probability of 0.000 . This value meets the requirements for acceptance of $\mathrm{H} 4$, namely the $\mathrm{CR}$ value of 4.196 which is greater than the table value of 1.97.This means that the better the information technology infrastructure, the better the good governance of the Department. Conversely, when the quality of information infrastructure decreases, these conditions can have a negative impact on the good governance.

\section{H5 is accepted : The Effect of Quality of HR on good governance}

The quality ofHR on employee good governance shows a CR value of 2.898 and with a probability of 0.000 . The two values obtained meet the requirements for acceptance of H3, namely the CR value of 2.898 which is greater than the table value of 1.97. This describes that improving the quality ofHR can also significantly affect the good governance. The more qualityHR the better good governance in the Aceh PersonnelDepartment.

\section{H6 is accepted : The Effect of organizational culture on good governance}

The influence of organizational culture on good governance shows a CR value of 5.144 and a probability of 0.000 . Thus the conditions for receipt of $\mathrm{H} 2$ have been received, namely the CR value of 5.144 which is greater than the table value of 1.97.This indicates that the better the organizational culture manifested in the form of values and norms that applies in the Aceh Personnel Department, the better the good governance in the Department.

\section{H7 is accepted : The e-government Influence on good governance}

The effect of e-government on good governance shows a CR value of 4.796 and a 


\section{International Journal of Business Management and Economic Review}

Vol. 2, No. 06; 2019

ISSN: 2581-4664

probability of 0,000 . Both of these values are obtained fulfilling the conditions for acceptance of $\mathrm{H} 7$, namely the CR value of 4.796 which is greater than the table value of 1.97 . This indicates that the better the e-governance that applies in the Aceh Personnel Department, the better the good governance in the Department.

\section{CONCLUSION}

The result proves that information technology has a significant effect on e-government; HR has a significant effect on e-government; organizational culture has a significant effect on egovernment; information technology has a significant effect on good governance; HR has a significant effect on good governance; organizational culture has a significant effect on good governance, and; e-government has a significant effect on good governance. Theseresearch findings have implications that efforts to implement good governance in these institutions can be done through policy interventions related to improving information technology, increasing the quality of employee HR and the implementation of organizational values and culture. These also contribute to the science area that can be an update causality theories related to the variables. This model is able to be a reference for the further research especially in the field of management and organization. The originality lies in the combination of the models fro the previous causality theories, and the test method using SEM. The limitation is in the number of variables and object.

\section{REFERENCES}

Byrd, T. A. and Turner, D. E. (2000) 'Measuring the flexibility of information technology infrastructure: Exploratory analysis of a construct', Journal of Management Information Systems, 17(1), pp. 167-208. doi: 10.1080/07421222.2000.11045632.

Harris, S. G. and Mossholder, K. W. (1996) 'Journal of Management during Organizational Transformation The Affective Implications of Perceived Congruence with Culture Dimensions On behalf of: Southern Management Association can be found at: Journal of Management Additional services and information', Journal of Management, 22(4), pp. 527-547. doi: 10.1177/014920639602200401.

Indrajit, R. E. (2002) Electronic government: strategi pembangunan dan pengembangan sistem pelayanan publik berbasis teknologi digital. Yogyakarta: Andi.

Khanh, N. T. V. (2014) 'The critical factors affecting E-Government adoption: A Conceptual Framework in Vietnam'. Available at: http://arxiv.org/abs/1401.4876.

Kumar, R. and Best, M. L. (2006) 'Impact and sustainability of E-government services in developing countries: Lessons learned from Tamil Nadu, India', Information Society, 22(1), pp. 1-12. doi: 10.1080/01972240500388149.

Mahdani (2009) 'Lingkungan Teknologi dan produktivitas Perusahaan Manufaktur', Jurnal Visi EKonomi, 8, pp. 07-17.

Mohamed, S., Haderi, A. and Ahmed, F. Bin (2015) 'The Negative Effect of Organization Culture Could Slow the Usage or the Adoption for the Technology', International Journal of Business and Social Science, 6(9), pp. 47-55.

Pratikno (2005) 'Daftar Isi HAM di Indonesia: Menuju Democratic Governances', Jurnal Ilmu Sosial dan Ilmu Politik, 8(3), pp. 1-19.

Robbins, S. P. and Judge, T. A. (2012) Organizational Behavior. 15th edn. Edited by S. Yagan. 
International Journal of Business Management and Economic Review

Vol. 2, No. 06; 2019

ISSN: 2581-4664

San Diego: Pearson.

Ruslan, Mukhlis and Mahdani (2015) 'Pengaruh Kompetensi Pendidikan Dan Pelatihan, Motivasi Dan Disiplin Kerja Terhadap Kinerja Pegawai Serta Dampaknya Pada Kinerja Dinas Perindustrian Dan Perdagangan Aceh', Jurnal Manajemen Pascasarjana Unsyiah, 4(4), pp. 1-10.

Sagita, A. D., Musnadi, S. and Shabri, M. (2017) 'Optimalisasi Pengelolaan Keuangan Berbasis Tata Kelola Pemerintahan Yang Baik Dan Dampaknya Terhadap Kinerja Pemerintahan Daerah Kabupaten Aceh Jaya', Jurnal Manajemen Pascasarjana Unsyiah, 6(1).

Suharto, A. A. (2012) 'Pengaruh Kualitas Sumber Daya Manusia, Komitmen dan Motivasi Terhadap e-government Pada Inspektorat Kabupaten Kediri', Jurnal Ilmu Manajemen, REVITALISAS, 1(3), pp. 67-79.

Tunggal, A. W. (1995) Akuntansi sumber daya manusia. Jakarta: Rineka Cipta. 